\title{
DAMPAK KEBERADAAN DUSUN BAMBU TERHADAP KONDISI SOSIAL EKONOMI MASYARAKAT DI DESA KERTAWANGI KECAMATAN CISARUA
}

\author{
Hasny Sutiarani ${ }^{1)}$, Fitri Rahmafitria ${ }^{2)}$ \\ Program Studi Manajemen Resort \& Leisure. \\ Fakultas Pendidikan Ilmu Pengetahuan Sosial. \\ Universitas Pendidikan Indonesia.
}

\begin{abstract}
ABSTRAK
Desa Kertawangi merupakan salah satu desa yang berada di Kecamatan Cisarua Kabupaten Bandung Barat Jawa Barat. Memiliki jumlah populasi sebanyak 11.394. Pada Januari 2014 telah dibuka kawasan wisata Dusun Bambu yang berada di lingkungan masyarakat Desa Kertawangi. Sebagian masyarakat merasa terbatas dalam menjalankan aktivitasnya. Namun di sisi lain keberadaan Dusun Bambu membuka lapangan pekerjaan bagi masyarakat. Hal inilah yang membuat penulis ingin mengetahui dampak keberadaan Dusun Bambu terhadap kondisi sosial ekonomi masyarakat di Desa Kertawangi Kecamatan Cisarua. Penelitian ini menggunakan metode deskriptif melalui pendekatan kuantitatif serta menggunakan kuisioner sebagai teknik pengumpulan data di lapangan dengan hasil penelitian. Data yang terkumpul diolah menggunakan teknik analisis paired sample $t$ test dibantu menggunakan software SPSS 22. Berdasarkan hasil penelitian diketahui bahwa terdapat perbedaan jumlah kondisi sosial ekonomi sebelum dan sesudah kebaradaan Dusun Bambu. Kondisi ekonomi mengalami peningkatan setelah keberadaan Dusun Bambu. Sementara kualitas social masyarakat mengalami penurunan. Uji t-test juga menunjukkan nilai beda yang signifikan yang menunjukan bahwa masyarakat Desa Kertawangi merasakan dampak positif dan negatif dengan adanya kawasan wisata Dusun Bambu. Pihak pengelola dan masyarakat harus bekerja sama dalam meminimalisir pengendalian dampak, seperti membuat aktivitas wisata yang dapat melibatkan masyarakat dan membuat program wisata untuk pelestarian lingkungan sekitar.
\end{abstract}

Kata Kunci: Perkembangan Pariwisata, Dampak, Masyarakat, Sosial, Ekonomi. 


\title{
THE IMPACT OF DUSUN BAMBU EXISTENCE ON SOCIO- ECONOMIC CONDITION IN KERTAWANGI VILLAGE-CISARUA REGENCY
}

\begin{abstract}
Kertawangi is a village in Cisarua Regency, West Bandung District, West Java. It has 11.394 citizens. As a destination, Dusun Bambu, was start to operate in January 2014, and it is located inside Kertawangi village. Still starting to open, the numbers of visitor come to Dusun Bambu are getting higher. This condition directly gives some impact to the daily activities of local community. Some people feel limited in doing their activities. But in the other side, Dusun Bambu existence creating jobs field for society. The objective of this research is to find out the impact of Dusun Bambu existence on community socio-economic condition in Kertawangi village, Cisarua Regency. This research used descriptive method by quantitative approach and using questionnaire to collecting data in field with observation result. Collected data processed using paired sample t test analysis technique, by SPSS 22. Based on the result, the economic condition of local people is increase after Dusun Bambu started to operate. But the quality of social conditioan is decrease, regarding to some changing in local people behavior and tradition. The result of t-test analysis also shows a significance difference that indicates that the local people feel both positive and negative impacts by the existence of Dusun. The management of Dusun Bambu should have some dealing program for the local community regarding to increase the positive impact and decrease the negative impact that caused by its existence.
\end{abstract}

Keywords: Tourism Development, Impact, Community, Social, Economic.

\section{PENDAHULUAN}

Pariwisata saat ini sedang menjadi salah satu fokus pemerintah, karena sektor pariwisata di Indonesia mempunyai peran penting untuk menghasilkan devisa bagi negara. Pariwisata di Indonesia sudah termasuk kedalam industri kreatif. Maka dari itu pembangunan pariwisata akan memberikan dampak yang besar bagi masyarakat, karena semakin banyak peluang untuk menciptakan industri-industri kreatif yang bisa menjadi sumber lapangan kerja yang baru untuk masyarakat lokal di sekitar pembanguanan pariwisata. Hal ini lah yang berpengaruh pada pertumbuhan ekonomi di Indonesia. Seperti yang diungkapkan oleh (Yoeti, 2008:21) bahwa pariwisata dapat menciptakan kesempatan bekerja dan berusaha, dapat meningkatkan pendapatan sekaligus mempercepat pemerataan pendapatan masyarakat, meningkatkan penerimaan pajak pemerintah, meningkatkan pendapatan nasional, dan memperkuat neraca pembayaran. Namun di sisi lain pengembangan pariwisata tidak hanya dapat dilihat dari pembangunan sektor ekonomi saja, akan tetapi ada dampak lain yang akan 
muncul, seperti dampak lingkungan, budaya, agama dan hal yang paling menarik adalah dampak sosial masyarakat sekitar. Dampak secara sederhana bisa diartikan sebagai pengaruh atau akibat. Dalam Kamus Besar Bahasa Indonesia dampak diartikan sebagai pengaruh kuat yang mendatangkan akibat, baik negatif maupun positif.

Perkembangan pariwisata di Indonesia salah satunya berada di Kabupaten Bandung Barat, Jawa Barat. Kabupaten Bandung Barat merupakan daerah sejuk yang relatif dingin sehingga banyak pengunjung datang untuk berwisata menghabiskan waktu libur. Selain identik dengan udara sejuknya Kabupaten Bandung Barat memiliki kekayaan alam yang banyak dimanfaatkan untuk sektor pariwisata. Seperti halnya Gunung Tangkuban Perahu, Wisata Alam Maribaya, Situ Ciburuy, Curug Malela, Situ Lembang dan masih banyak tempat wisata alam lainnya. Dengan banyaknya potensi-potensi alam yang ada maka banyak pengembang-pengembang pariwisata yang tertarik untuk membangun sektor pariwisata di daerah Kabupaten Bandung Barat. Seperti halnya pembangunan hotel, restoran, cafe dan resort.

Pengembangan pariwisata yang begitu pesat di daerah Kabupaten Bandung Barat tentunya memiliki dampak yang ditimbulkan kepada daerah-daerah yang berada di kawasan wisata tersebut. Terutama bagi masyarakat sekitar, seperti yang disebutkan bahwa, Pariwisata adalah suatu kegiatan yang secara langsung menyentuh dan melibatkan masyarakat, sehingga membawa berbagai dampak terhadap masyarakat setempat (Pitana, 2005:109). Kawasan wisata Kabupaten Bandung Barat sangat beragam. Dari mulai wisata alam sampai dengan wisata buatan yang dikelola oleh pemerintah maupun pihak swasta. Disini bisa dilihat bahwa pembangunan kawasan wisata di daerah tersebut sangat berkembang pesat. Hampir setiap kecamatan yang ada di Kabupaten Bandung Barat memiliki tempat kawasan wisata. Terutama Kecamatan Parongpong dan Kecamatan Cisarua yang memiliki tempat wisata yang paling banyak diantara kecamatan lainnya, disusul dengan kecamatan Lembang yang ada di posisi ke dua. Namun yang menarik adalah pada kecamatan Cisarua tepatnya di Desa Kertawangi terdapat empat lokasi wisata diantaranya Curug Cimahi, Curug Bugbrug, Situ Lembang dan Dusun Bambu yang sekarang menjadi tempat favorit untuk menghabiskan waktu berakhir pekan. 
Tabel 1.1 Mata Pencaharian Pokok Desa Kertawangi:

\begin{tabular}{|l|c|c|c|c|}
\hline \multicolumn{5}{|c|}{ Mata Pencaharian Pokok } \\
\hline Ahli Pengobatan Alternatif & 1 orang & O orang & 1 orang & $\mathbf{1 4}$ \\
\hline Bidan swasta & O orang & 2 orang & 2 orang & $\mathbf{1 3}$ \\
\hline Buruh Tani & 200 orang & 100 orang & 300 orang & $\mathbf{2}$ \\
\hline Dokter swasta & 0 orang & 2 orang & 2 orang & $\mathbf{1 3}$ \\
\hline Dosen swasta & 2 orang & O orang & 2 orang & $\mathbf{1 3}$ \\
\hline Dukun Tradisional & 1 orang & 2 orang & 3 orang & $\mathbf{1 2}$ \\
\hline Montir & 25 orang & 0 orang & 25 orang & $\mathbf{1 0}$ \\
\hline Pedagang Keliling & 30 orang & 2 orang & 32 orang & $\mathbf{9}$ \\
\hline Pegawai Negeri Sipil & 110 orang & 75 orang & 185 orang & $\mathbf{3}$ \\
\hline Pembantu rumah tangga & 0 orang & 37 orang & 37 orang & $\mathbf{7}$ \\
\hline Pengrajin & 25 orang & 10 orang & 35 orang & $\mathbf{8}$ \\
\hline Perangkat Desa & 10 orang & 2 orang & 12 orang & $\mathbf{1 1}$ \\
\hline Petani & 480 orang & 20 orang & 500 orang & $\mathbf{1}$ \\
\hline Peternak & 120 orang & 25 orang & 145 orang & $\mathbf{4}$ \\
\hline Purnawirawan/Pensiunan & 42 orang & 15 orang & 57 orang & $\mathbf{5}$ \\
\hline TNI & 40 orang & 0 orang & 40 & $\mathbf{6}$ \\
\hline Jumlah Total Penduduk & 1.378 orang & \\
\hline
\end{tabular}

Sumber : Profil Desa Kertawangi 2013

Desa Kertawangi merupakan salah satu desa dengan jumlah penduduk mencapai 11.394. Data ini diperoleh dari profil desa Kertawangi tahun 2013. Masyarakatnya didominasi dengan mata pencaharian pokok sebagai petani sesuai dengan tabel 1.1 tentang mata pencaharian pokok masyarakat Desa Kertawangi. Lokasi desa yang berada di dataran tinggi membuat tanah di kawasan tersebut sangat subur. Maka tidak heran bahwa mata pencaharian pokok penduduk yang paling banyak menghasilkan dari segi ekonominya. Lahan pertanian di dominasi oleh sayuran.

Sesuai dengan tabel yang bersumber dari profil desa Kertawangi mata pencaharian sebagai petani ada di urutan pertama dengan jumlah 500 orang. Di urutan kedua yaitu buruh tani dengan jumlah 300 orang. Ini membuktikan bahwa sebagian besar mata pencahariann penduduk Desa Kertawangi di dominasi oleh petani dan buruh tani. Sedangkan yang paling sedikit adalah mata pencaharian sebagai dokter dan dosen swasta hanya berjumlah masing-masing 2 orang saja. Banyak masyarakat yang menggantungkan hidupnya dari hasil bertani, meskipun penghasilan sebagai buruh tani tidak sebanyak apabila kita bekerja di perusahaan-perusahaan. Namun dengan menjadi seorang buruh tani mereka tidak perlu mengunakan kualifikasikualifikasi yang khusus. Sehingga demi memenuhi kebutuhan sehari-harinya mereka memilih pekerjaan sebagai petani atau buruh tani. Masalah pekerjaan di lingkungan masyarakat desa Kertawangi salah satunya adalah latar belakang pendidikan yang masih rendah.

Menurut Mill dalam bukunya yang berjudul "The Tourism, International Business" (Mill, 2000:168-169) "Pariwisata dapat memberikan keuntungan bagi 
wisatawan maupun komunitas tuan rumah dan dapat menaikan taraf hidup melalui keuntungan secara ekonomi yang dibawa ke kawasan tersebut". Dari pernyataan tersebut, penduduk desa Kertawangi bisa bekerja di tempat-tempat kawasan wisata tersebut karena secara otomatis kawasan wisata membuka lapangan pekerjaan atau membuka usaha sendiri untuk pendukung kawasan wisata tersebut seperti menjual makanan khas daerah ataupun penjual. Namun jika dilihat dari sisi negatif dengan banyaknya kawasan wisata ada dampak yang ditimbulkan khususnya kepada masyarakatnya, seperti yang dituturkan oleh Bapak Ujang Kurnia selaku sekertaris Desa Kertawangi. Beliau menuturkan bahwa dengan adanya kawasan wisata yang ada di desanya maka dampak yang paling terasa adalah kemacetan yang selalu terjadi kawasan desa Kertawangi terlebih ada destinasi yang sedang populer saat ini yaitu kawasan wisata Dusun Bambu. Dusun Bambu merupakan kawasan wisata yang baru di buka sekitar Januari 2014. Namun antusias masyarakat terhadap lokasi tersebut sangatlah tinggi. Hampir setiap akhir pekan kawasan tersebut selalu di penuhi oleh wisatawan. Wisatawan yang paling banyak adalah pendatang dari Ibu Kota Jakarta.

Penulis menemukan tiga artikel via internet salah satunya dari Tribune.co.id Simpul Kemacetan Lembang di Tempat Wisata Dusun Bambu - Tribun Jabar yang berisi tentang kemacetan yang terjadi sepanjang jalan menuju lokasi wisata Dusun Bambu. Kemudian adanya keluhan dari peternak sapi akibat dari macet sepanjang jalan menuju Dusun Bambu, Lokasi peternakan Sapi ada di atas Dusun Bambu dan untuk menuju lokasi peternak melalui jalan yang sama, sumber Bisnis Hotel.html. Ditambah penulis menemukan artikel tentang kejadian-kejadian tentang masyarakat Desa Kertawangi dari mulai demo hingga adanya kasus kriminalitas yang terjadi.

Teori terkait dampak pariwisata. Pariwisata merupakan serangkaian kegiatan yang dilakukan oleh wisatawan yang secara langsung menyentuh dan melibatkan masyarakat sehingga membawa berbagai dampak terhadap masyarakat setempat. Dampak pariwisata terhadap masyarakat dan daerah tujuan wisata yang banyak mendapat ulasan adalah dampak terhadap ekonomi, terhadap sosial budaya serta terhadap lingkungan (Ismayanti, 2010, hlm. 181-183). Maka dari pernyataan ahli tersebut sebagai dasar awal untuk mencari tahu dan mengidentifikasi lebih lanjut tentang Dampak pariwisata yang terjadi di daerah Desa Kertawangi akibat adanya pembangunan Dusun Bambu. Dampak tersebut lebih di fokuskan dari persepsi masyarakat terhadap keberadaan Dusun Bambu agar mengetahui perbedaan kondisi masyarakat sebelum dan setelah keberadaan Dusun Bambu dari segi Ekonomi dan Sosial. Mengapa demikian karena dari hasil wawancara dan survey langsung kepada penduduk Desa Kertawangi dampak yang paling mennonjol ada di kedua aspek tersebut. Tentunya yang terjadi tidak hanya dampak negatif saja namun akan ada dampak postif yang dirasakan langsung oleh masyarakat Desa Kertawangi. 


\section{METODOLOGI PENELITIAN}

Lokasi penelitian mengambil di Desa Kertawangi, Kecamatan Cisarua, Kabupaten Bandung Barat, Jawa Barat. Lokasi ini merupakan lokasi dimana banyak pembangunan lokasi wisata seperti Curug Cimahi, Situ Lembang, Curug Bubrug dan Dusun Bambu. Metode yang digunakan pada penelitian ini adalah metode deskriptif. Menurut (Sugiyono, 2011:35) penelitian deskriptif penelitian yang dilakukan untuk mengetahui variabel mandiri, baik satu variabel atau lebih tanpa membuat perbandingan, atau menghubungkan dengan variabel lain. (Nazir, 2005:54), metode deskriptif adalah suatu metode dalam meneliti status sekelompok manusia, suatu obyek, suatu set kondisi, suatu sistem pemikiran, ataupun suatu kelas peristiwa pada masa sekarang.. Tujuan dari penelitian deskriptif ini adalah untuk membuat deskripsi, gambaran atau lukisan secara sistematis mengenai dampak keberadaan Dusun Bambu terhadap kondisi ekonomi masyarakat. Data yang nanti akan diperoleh adalah data primer dan sekunder. Data primer akan diperoleh dari masyarakat Desa Kertawangi yang merasakan dampak keberadan Dusun Bambu. Kemudian data sekunder akan diperoleh dari orang kedua atau pihak lain dalam hal ini bisa berbentuk informasi dari Kantor Desa atau pihak lain yang dapat membantu dalam melengkapi data penelitian ini. Lalu metode deskriptif ini akan memakai data kuantitatif yang nantinya akan di olah secara statistik. Sampel yaitu 100 penduduk Desa Kertawangi dan dihitung menggnakan rumus Slovin (Sinamora, 2004:15) untuk menentukan jumlah sampel dari penduduk Desa Kertawangi.

Teknik analisis data kuisioner menggunakan skala likert. Metode analisis data menggunakan paired sample t-test untuk mengetahui dampak sosial ekonomi setelah keberadaan Dusun Bambu dilihat dari perbedaan rata-rata kondisi sosial ekonomi masyarakat sebelum dan sesudah keberadaan Dusun Bambu.

\section{HASIL DAN PEMBAHASAN}

\section{Kondisi Ekonomi Sebelum Keberadaan Dusun Bambu}

Tingkat Masyarakat yang sudah memiliki penghasilan atau pekerjaan sebelum keberadaan Dusun Bambu masih rendah. Hal ini dikarenakan tingkat pendidikan masyarakat yang hanya mengenyam pendidikan hingga sekolah dasar. Masyarakat megeluhkan sulitnya mencari pekerjaan terlebih harus mencari ke kota atau bekerja sebagai karyawan, sehingga masyarakat hanya mengandalkan sektor pertanian sebagai sumber yang bisa diandalkan. Pendapatan dari seorang buruh tani hanya mencapai Rp 25.000 per hari. Kondisi ini deperparah oleh harga-harga sembako di warung dan di pasar lokal yang tidak stabil. Hal ini dikarenakan harga BBM yang terus meningkat hingga meyebabkan ketidakstabilan harga kebutuhan pokok terutama pada sembako. Tentunya ketidakstabilan harga menjadi beban tersendiri bagi masyarakat.

Produktivitas hasil pertanian dan pertenakan sebagai andalan masyarakat Desa Kertawangi memang sudah tinggi. Hal ini dikarenakan bahwa lahan pertanian di 
Desa Kertawangi berada di ketinggian yang menyebabkan lahan tersebut menjadi subur. Selain pertanian sebagian masyarakat berprofesi sebagai peternak sapi perah. Namun sangat disayangkan hasil-hasil dari pertanian dan susu perah masyarakat tidak dimanfaatkan oleh para pelaku usaha wisata lokal. Menurut salah seorang peternak susu sapi hasil-hasil dari sektor perternakan dan pertanian tersebut lebih memilih menjualnya ke pasar atau tengkulak dibandingkan harus dibeli dengan jumlah yang sedikit kepada para pelaku usaha wisata lokal. Tingkat pembangunan fasilitas umum sebelum keberadaan Dusun Bambu masih rendah. Masyarakat berpendapat bahwa hasil-hasil pembangunan seperti mushola dan masjid masih dilakukan oleh dana dari hasil iuran seluruh warga desa serta kas kencleng dari para pengguna jalan. Prasarana jalan pun masih alakadarnya belum dilakukan pengaspalan.

Seacara umum apabila di lihat dari teori kondisi sosial ekonomi. Menurut Melly G Tan (Koentjaraningrat, 1990) bahwa golongan ekonomi rendah yaitu keluarga yang menerima pendapatan lebih rendah dari keperluan untuk memenuhi tingkat hidup yang minimal. Bila dilihat dari teori tersebut masyarakat Desa Kertawangi memang memiliki penghasilan yang rendah karena pekerjaan mereka rata-rata hanya sebatas buruh tani, yang penghasilan perbulannya mencapai Rp.1.500.000. Mereka menyatakan bahwa untuk mencari pekerjaan di Kota sangat sulit karena kualifikasi rata-rata setiap perusahaan minimal menerima karyawan dengan pendidikan terakhir sampai dengan tingkat Sekolah Menengah Atas. Sementara Sumber Daya Manusia di Desa Kertawangi di usia-usia produktif yang cocok untuk bekerja mereka hanya mengenyam pendidikan sampai dengan Sekolah Dasar saja. Akibatnya mereka tidak ada pilihan untuk melakukan pekerjaan apa saja asalkan menghasilkan uang untuk kebutuhan sehari-hari mereka.

Tingkat masyarakat yang sudah memiliki penghasilan atau pekerjaan setelah keberadaan Dusun Bambu masih rendah. Artinya dengan hasil seperti ini Dusun Bambu belum berkontribusi banyak terhadap masyarakat dalam soal perkerutan karyawan Dusun Bambu itu sendiri. Menurut masyarakat sekitar, pengelola Dusun Bambu memang sudah memperkerjakan sebagian masyarakat Desa Kertawangi untuk bekerja di kawasan wisata tersebut. Namun tidak semua masyarakat bisa bekerja di kawasan tersebut karena semua posisi sudah terisi. Sehingga masih banyak masyarakat yang ingin bekerja di kawasan wisata tersebut namun kuota karyawannya sudah penuh, sehingga harus menunggu panggilan dari pihak pengelola kawasan wisata.

Apabila dilihat dari tingkat pendapatan ada perbedaan kondisi. Hal ini dikarenakan bahwa semenjak keberadaan Dusun Bambu memang ada sebagian masyarakat yang bekerja di kawasan wisata tersebut. Namun lagi-lagi dengan keterbatasan latar belakang pendidikan yang rata-rata hanya mencapai tingkat sekolah dasar saja sehingga posisi yang diemban pun hanya sebatas cleaning service, tukang kebun, tukang parkir, keamanan, bagian dapur dan pramusaji saja. Namun keuntungan masyarakat yang bekerja di Dusun Bambu merasa bahwa mereka mempunyai penghasilan yang tetap, walaupun sebenarnya masyarakat merasa bahwa penghasilan mereka sebelum dan setelah keberadaan Dusun Bambu tidak berubah 
secara signifikan. Harga-harga kebutuhan pokok memang tidak ada pengaruh setelah keberadaan Dusun Bambu terhadap harga-harga kebutuhan pokok yang semakin tidak stabil. Menurut masyarakat sekitar bahwa penyebab ketidak stabilan harga-harga pokok di pasar atau warung lokal adalah pemerintah itu sendiri. Terutama pada kenaikan harga beras, rempah-rempah dan gas elpiji $3 \mathrm{~kg}$. Tidak ada pengaruh kenaikan harga yang disebabkan dengan adanya kawasan wisata Dusun Bambu karena warung lokal atau pasar hanya mengikuti harga dari pemerintah.

Terjadi perbedaan kondisi dimana produktivitas pertanian dan pertenakan masyarakat lokal setelah keberadaan Dusun Bambu menjadi rendah. Artinya Dusun Bambu belum mendukung hasil pemanfaatan pertanian atau pertenakan yang dimiliki oleh masyarakat Desa Kertawangi. Menurut masyarakat, pengelola Dusun Bambu mengambil bahan-bahan pokok untuk kebutuhan dapur langsung dari distributor pasar. Kemudian penurunan terjadi pada produktivitas hasil pertanian. Hal dikarenakan pihak pengelola Dusun Bambu mengambil alih sebagian lahan pertanian masyarakat untuk dikembangkan menjadi sebuah kawasan wisata Dusun Bambu. Tentunya sebagian masyarakat kecewa dengan adanya perluasan lahan yang mengakibatkan penurunan produktivitas hasil pertanian masyarakat Desa Kertawangi. Tingkat pembangunan fasilitas umum setelah keberadaan Dusun Bambu terjadi perubahan. Masyarakat berpendapat setelah keberadaan Dusun Bambu pembangunan seperti jalan yang mulai di aspal, penerangan yang sudah semakin banyak menjadi kesan yang positif bagi lingkungan Desa Kertawangi.

Secara umum kondisi ekonomi masyarakat Desa Kertawangi setelah keberadaan Dusun Bambu memang masih belum berbeda jauh dari kondisi ekonomi masyarakat Desa Kertawangi.

Sebelum keberadaan Dusun Bambu. Semenjak keberadaannya pada awal tahun 2014 tepatnya di Bulan Januari 2014. Dusun Bambu sudah menjadi kawasan wisata yang sudah terkenal di kawasan wisata Kabupaten Bandung Barat. Cukup hanya dengan waktu kurang lebih satu tahun Dusun Bambu sudah mendatangkan wisatawan dari berbagai daerah dan tentunya dari berbagai negara. Namun dengan adanya kawasan wisata tersebut masyarakat belum bisa banyak membuat perubahan kondisi ekonomi masyarakat. Harapan masyarakat ketika mengetahui akan dibangun sebuah kawasan wisata tentunya harapan pertama yaitu bisa merubah kondisi ekonomi masyarakat. Setidaknya dengan memberikan peluang untuk bekerja sehingga mereka bisa lebih sejahtera. Lahan pertanian pun menjadi semakin kecil dengan adanya perluasan kawasan wisata sehingga menurunkan tingkat produktivitas hasil pertanian masyarakat Desa Kertawangi.

Struktur populasi Desa Kertawangi sebelum keberadaan Dusun Bambu masih stabil. Artinya disini bahwa pertumbuhan penduduk tidak ada perubahan yang signifikan, kelahiran dan kematian berjalan normal atau stabil. Tidak banyak masyarakat baru yang pindah dari daerah lain yang menetap di Desa Kertawangi sehingga mempengaruhi struktur populasi. Mata pencaharian atau profesi masih belum banyak berubah. Profesi yang dilakoni oleh masyarakat yang terbanyak adalah sebagai buruh tani. 
Kepedulian masyarakat Desa Kertawangi dalam menjaga etika pergaulan, adat istiadat dan kesederhanaan sudah tinggi. Selain itu juga adat istiadat desa masih sering dilakukan terutama untuk hari-hari besar Agama Islam. Kesopanan masyarakat pun masih sangat terjaga sehingga membuat lingkungan Desa pun terasa nyaman dan tentram. Pernyataan tersebut diperkuat oleh hasil wawancara yang dilakukan oleh peneliti kepada Bapak Ujang selaku tokoh masyarakat sekaligus yang menjabat sebagai sekertaris Desa Kertawangi. Menurut beliau kondisi tata pergaulan masyarakat sebelum keberadaan Dusun Bambu berjalan sederhana, maksudnya masyarakat sangat memegang teguh kesopanan dalam pergaulan, sederhana dalam bertingkah laku sehingga terwujudnya lingkungan yang aman dan tentram. Kehidupan sehari-hari masyarakat desa mengenai kelancaran arus lalu lintas, kemudahan memperoleh air bersih, kebersihan udara, dan kemanan lingkungan memang sudah tinggi. Artinya lingkungan masyarakat dari mulai arus lalu lintas masih sepi tidak menimbulkan kemacetan sehingga polusi udara pun sedikit sekali. Pendatang atau wisatawan pun masih rendah untuk berkunjung datang ke Desa Tersebut. Apabila ada wisatawan yang datang tujuannya untuk ke Situ Lembang, Curug Cimahi dan para TNI yang berlatih khusus di daerah pegunungan Burangrang yang akses masuknya melewati Desa Kertawangi. Untuk air bersih, Desa Kertawangi memiliki sumber mata air yang mengaliri seluruh tempat tinggal masyarakat Desa Kertawangi. Bahkan sumber mata air tersebut mampu mengaliri sebagian Kota Cimahi. Dari sisi kemananan masyarakat Desa Kertawangi membudayakan penjagaan malam dengan program pos kamling.

Struktur populasi Desa Kertawangi setelah keberadaan Dusun Bambu menurun menjadi rendah. Artinya disini ada perubahan struktur populasi setelah keberadaan Dusun Bambu menjadi tidak stabil. Menurut masyarakat setelah keberadaan Dusun Bambu banyak masyarakat pendatang yang menetap tinggal di Desa Kertawangi. Hal ini sangat berpengaruh pada struktur populasi Desa Kertawangi. Struktur perubahan mata pencaharian/profesi masyarakat di Desa setelah keberadaan Dusun Bambu menjadi tinggi. Artinya masyarakat Desa Kertawangi dalam mata pencaharian atau profesi sudah mulai berubah. Profesi atau pekerjaan masyarakat yang berubah dari seorang buruh tani menjadi karyawan Dusun Bambu. Sebagian masyarakat lebih memilih menjadi karyawan Dusun Bambu dengan harapan mendapat penghasilan yang lebih besar. Tetapi ada sebagian masyarakat yang masih memilih menjadi seorang buruh tani daripada bekerja sebagai karyawan Dusun Bambu. Pendapat lain dikeluhkan oleh sebagian masyarakat terutama wanita, mereka menyebutkan bahwa setelah keberadaan Dusun Bambu mereka kehilangan pekerjaannya. Hal ini dikarenakan bahwa sebagian ladang pertanian masyarakat diambil alih oleh pihak pengelola kawasan Dusun Bambu.

Kepedulian masyarakat Desa Kertawangi dalam menjaga gaya hidup pergaulan di masyarakat berubah menjadi rendah. Banyak faktor yang mengubah masyarakat. Salah satu faktornya adalah adanya pendatang dari daerah lain yang tentunya membawa kebiasaan atau kebudayaan masing-masing. Menurut Bapak Ujang selaku tokoh masyarakat sekaligus sebagai sekertaris Desa sebagian perubahan 
terjadi karena ingin meniru atau masyarakat ingin kehidupan yang lebih modern. Sehingga berpengaruh pada pola pikir dan tingkah laku mereka. Terlebih ketika ada kawasan wisata Dusun Bambu, pengunjung yang datang ke kawasan wisata tersebut rata-rata berasal dari kota. Sehingga bukan tidak mungkin bahwa masyarakat melihat serta mengikuti tingkah laku 'ala' masyarakat kota.

Kehidupan dalam keseharian masyarakat setelah keberadaan Dusun Bambu dalam kemudahan memperoleh air bersih masyarakat tidak menemukan kesulitan. Tingkat kemanan lingkungan masih aman. Tetapi sempat terjadi kasus pembunuhan yang melibatkan karyawan Dusun Bambu, namun tempat kejadian pembunuhan dan pelaku pembunuhan bukan berasal dari Masayarakat Desa Kertawangi. Perubahan justru terjadi pada tingkat pendatang wisatawan, arus lalu lintas, dan tingkat kebersihan udara. Kawasan wisata Dusun Bambu merupakan kawasan wisata yang diresmikan pada Januari 2014 lalu. Semenjak awal pertama kali dibuka hingga sekarang pengunjung terus ramai berdatangan untuk mengunjungi lokasi wisata tersebut. Pengunjung yang berasal dari segala penjuru daerah datang, hingga menimbulkan kemacetan yang parah di sekitar jalan menuju lokasi wisata Dusun Bambu. Akibatnya masyarakat merasa terganggu dengan kemacetan tersebut.

Dengan adanya kemacetan tentunya polusi udara pun timbul, masyarakat menyebutkan bahwa ketika arus lalu lintas macet asap kendaraan dari mobil atau motor pengunjung mengganggu kualitas udara lingkungan Desa Kertawangi. Selain asap kendaraan polusi suara pun terjadi, suara bising yang dihasilkan dari kendaraan bermotor mengganggu masyarakat bahkan beberapa masyarakat mengaku ketika ada kendaraan besar atau bus yang lewat, rumah-rumah yang dilalui oleh kendaraan tersebut sering bergetar. Akibatnya beberapa mengalami keretakan pada tembok, terutama rumah yang berada di pinggir jalan.

\section{Dampak Keberadaan Dusun Bambu Terhadap Kondisi Sosial Ekonomi Masyarakat Desa Kertawangi}

\section{Dampak Terhadap Kondisi Ekonomi Sumber: Olahan Peneliti 2015}

Pada tebel 1.1, dapat dilihat bahwa rata-rata kondisi ekonomi sebelum dan sesudah keberadaan Dusun Bambu meningkat dari 19,3719 menjadi 23,0005. Dari perbedaan mean tersebut dapat dikatakan bahwa terjadi perbedaan kondisi ekonomi sebelum dan setelah keberadaan Dusun Bambu artinya terjadi Dampak ekonomi setelah keberadaan Dusun Bambu. Dampak Ekonomi terlihat pada tabel paired samples statistics mengalami perubahan, dilihat dari angka mean yang berbeda pada sebelum dan sesudah keberadaan Dusun Bambu. Perbedaan mean tersebut menunjukan peningkatan, itu artinya terjadi dampak positif bagi masyarakat setelah keberadaan Dusun Bambu. Gambar garis kontinum 1.1 dan 1.2 menjelaskan mengenai kondisi masyarakat sebelum dan sesudah keberadaan Dusun Bambu. 


\begin{tabular}{|cc|c|c|c|} 
Sangat Rendah & Rendah & Netral & Tinggi & Sangat Tinggi \\
\hline
\end{tabular}

Gambar 1.1.

Garis Kontinum Kondisi Ekonomi Masyarakat Sebelum Keberadaan Dusun Bambu

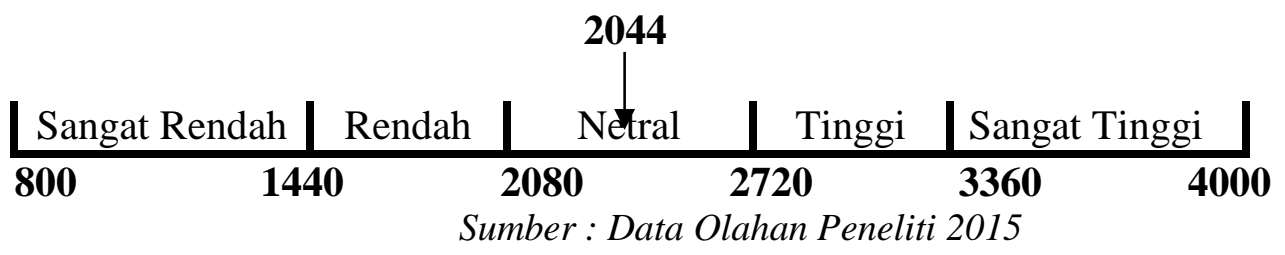

\begin{tabular}{|c|c|c|r|r|c|}
\hline \multicolumn{7}{|c|}{ Tabel 1.1 Paired Samples Statistics } \\
\hline & & \multicolumn{1}{|c|}{ Mean } & \multicolumn{1}{c|}{ N } & $\begin{array}{c}\text { Std. } \\
\text { Deviation }\end{array}$ & $\begin{array}{c}\text { Std. Error } \\
\text { Mean }\end{array}$ \\
\hline \multirow{2}{*}{ Pair 1 } & EKONOMI_SEBELUM & 19.3719 & 100 & 2.96907 & 0.29691 \\
\cline { 2 - 6 } & EKONOMI_SESUDAH & 23.0005 & 100 & 3.90267 & 0.39027 \\
\hline
\end{tabular}

\begin{tabular}{ccccc|c|} 
& Sangat Rendah & Rendah & Netral & Tinggi & Sangat Tinggi \\
\cline { 2 - 4 } & $\mathbf{1 4 4 0}$ & $\mathbf{2 0 8 0}$ & $\mathbf{2 7 2 0}$ & $\mathbf{3 3 6 0}$ & $\mathbf{4 0 0 0}$ \\
& & Sumber : Data Olahan Peneliti 2015 &
\end{tabular}

Gambar 1.2.

Garis Kontinum Kondisi Ekonomi Masyarakat Setelah Keberadaan Dusun Bambu

Sub variabel kondisi ekonomi diantaranya adalah pendapatan masyarakat, kesempatan kerja, terhadap harga, terhadap manfaat dan keuntungan terhadap kepemilikan, serta pembangunan fasilitas. Berdasarkan kategori diatas maka tanggapan masyarakat Desa Kertawangi mengenai kondisi ekonomi masyarakat sebelum keberadaan Dusun Bambu memperoleh jumlah total skor sebesar 1928. Sedangkan tanggapan masyarakat mengenai kondisi ekonomi setelah keberadaan Dusun Bambu memperoleh total skor sebesar 2044. Berdasarkan hasil tersebut terjadi kenaikan dari sebelum dan setelah keberadaan Dusun Bambu. Dengan melihat hasil 
pengolahan data kuisioner yang menunjukan bahwa terjadi kenaikan kondisi ekonomi masyarakat Desa Kertawangi sebelum dan setelah keberadaan Dusun Bambu, maka dapat disimpulkan teori (Cohen, 1984, dalam Pitana dan Gayatri, 2005:110) menyatakan bahwa pembagunan pariwisata akan membawa dampak ekonomi bagi masyarakat sekitar, maka dengan melihat penelitian ini teori Cohen 1984 dapat dinyatakan dengan benar, bahwa pembangunan pariwisata akan berdampak positif maupun negatif pada kondisi ekonomi masyarakat.

Dampak positif terbesar yaitu terjadi pada peningkatan pendapatan. Sedangkan dampak negatif aspek ekonomi terbesar yaitu penurunan produktivitas hasil pertanian dan peternakan. Masyarakat terbantu dengan keberadaan kawasan wisata Dusun Bambu, karena dapat menyediakan lapangan pekerjaan untuk masyarakat Desa Kertawangi. Dengan begitu masyarakat sedikit terbantu sehingga mereka dapat menerima penghasilan tetap dan tentunya bayaran yang lebih besar dari pada upah seorang buruh tani yang hanya mendapatkan Rp. 25.000 perhari kerja. Namun tidak semua masyarakat dapat bekerja di kawasan wisata Dusun Bambu karena kuota perekrutan karyawan terbatas.

Menurut Konsep multiplier effect di bidang ekonomi dapat dilihat dari PDRB, peningkatan pendapatan masyarakat, kemampuan menciptakan atau membuka lapangan kerja bagi masyarakat (Domanski \& Gwodz 2010:30). Dari pernyataan tersebut bahwa Keberadaan Dusun Bambu sudah menimbulkan multiplier effect bagi masyarakat Desa Kertawangi. Salah satunya adalah peningkatan pendapatan masyarakat. Peningkatan penghasilan terjadi bukan hanya masyarakat yang bekerja di kawasan Dusun Bambu saja, melainkan masyarakat yang berprofesi sebagai tukang ojek pun merasakan hal yang sama yaitu peningkatan penghasilan karena banyaknya pengunjung yang datang dan menggunakan jasa ojek untuk sampai ke lokasi Dusun Bambu. Selain itu dengan adanya kawasan wisata tentunya pajak penghasilan daerah pun menjadi meningkat dan itu berguna bagi pembagunan fasilitas, seperti jalan raya yang diperlebar dan diaspal serta penerangan di setiap jalan menuju kawasan Wisata Dusun Bambu

\section{Dampak Terhadap Kondisi Sosial}

\begin{tabular}{|l|l|r|r|r|c|}
\hline \multicolumn{7}{|c|}{ Tabel 1.2 Paired Samples Statistics } \\
\hline \multirow{3}{*}{ Pair 1 } & \multicolumn{1}{|c|}{ Mean } & N & Std. Deviation & $\begin{array}{c}\text { Std. Error } \\
\text { Mean }\end{array}$ \\
\hline & $\begin{array}{l}\text { SEBELUM_SO } \\
\text { SIAL }\end{array}$ & 35.8138 & 100 & 3.98519 & 0.39852 \\
\cline { 2 - 6 } & $\begin{array}{l}\text { SOSIAL_SESU } \\
\text { DAH }\end{array}$ & 30.9125 & 100 & 5.05489 & 0.50549 \\
\hline
\end{tabular}

Sumber: Olahan Data Peneliti 2015

Pada tabel 1.2., dapat dilihat bahwa rata-rata kondisi sosial sebelum keberadaan sebelum dan sesudah keberadaan Dusun Bambu mengalai penurunan dari 
35,8138 menjadi 30,9125. Kondisi sosial terlihat pada tabel paired samples statistics mengalami perubahan, dilihat dari angka mean yang berbeda pada sebelum dan sesudah keberadaan Dusun Bambu. Perbedaan mean tersebut menunjukan penuruan, itu artinya bahwa terjadi dampak negatif bagi masyarakat setelah keberadaan Dusun Bambu.

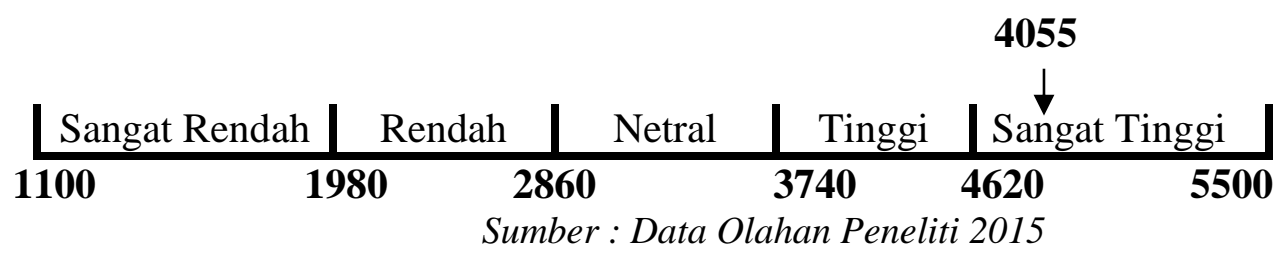

Gambar 1.3.

Garis Kontinum Kondisi Sosial Masyarakat Sebelum Keberadaan Dusun Bambu

3035

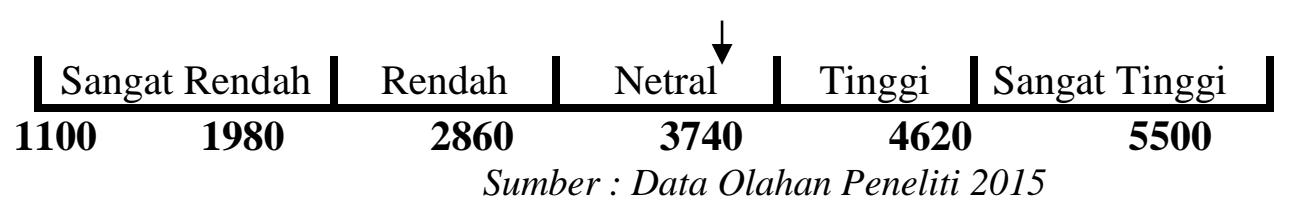

Gambar 1.4.

Garis Kontinum Kondisi Sosial Masyarakat Setelah Keberadaan Dusun Bambu

Sub variabel kondisi sosial adalah kondisi struktur populasi, transformasi struktur mata pencaharian, terhadap tata nilai, dan terhadap keseharian masyarakat. Berdasarkan kategori diatas maka tanggapan masyarakat Desa Kertawangi mengenai kondisi sosial masyarakat sebelum keberadaan Dusun Bambu memperoleh total skor sebesar 4055. Lalu tanggapan masyarakat mengenai kondisi ekonomi setelah keberadaan Dusun Bambu memperoleh total skor sebesar 3035. Berdasarkan hasil dari analisis tersebut terjadi penurunan dari sebelum dan setelah keberadaan Dusun Bambu. Dengan melihat hasil pengolahan data kuisioner yang menunjukan bahwa terjadi penurunan kondisi sosial masyarakat Desa Kertawangi sebelum dan setelah kebaradaan Dusun Bambu, maka dapat disimpulkan bahwa teori (Richard and Fluker, 2004:129-131) menyatakan bahwa pembagunan pariwisata akan membawa dampak sosial bagi masyarakat sekitar, maka dengan melihat penelitian ini teori Fluker 2004 dapat dinyatakan dengan benar, bahwa pembangunan pariwisata akan berdampak positif maupun negatif pada kondisi ekonomi masyarakat. Dampak negatif terbesar terjadi pada kondisi sosial masyarakat yaitu adanya perubahan sosial lingkungan fisik Desa Kertawangi. Seperti kemacetan yang sering kali dialami masyarakat. Dari kemacetan tersebut sangat menghambat kegiatan masyarakat dalam kesehariannya. Selain itu asap dari kendaraan bermotor membuat polusi udara, dan polusi suara di sekitar lingkungan masyarakat. Serta adanya sedikit perubahan dalam gaya hidup tata cara pergaulan di lingkungan dalam masyarakat Desa Kertawangi. Hal ini sesuai 
dengan konsep multiplier effect dalam bidang sosial bahwa dengan adanya industri di suatu daerah bisa menyebabkan efek negatif adalah menjadikan penduduk menjadi konsumtif ke arah yang lebih modern serta kualitas lingkungan hidup yang semakin berkurang. (Masrshall 1920:39-47). Maka dari itu Keberadaan Dusun Bambu dipandang masih belum bisa berkontribusi memberikan dampak positif terutama bagi kondisi sosial kepada masyarakat Desa Kertawangi.

\section{Upaya Pengendalian Dampak}

Pembahasan pengendalian dampak yaitu penurunan produktivitas hasil pertanian dan peternakan, perubahan sosial lingkungan fisik masyarakat dan tata nilai keseharian masyarakat. Pembahasan tersebut dipilih berdasarkan rumusan masalah dua yaitu mengenai dampak keberadaan Dusun Bambu. Terjadi penurunan produktivitas hasil pertanian, terdapat penurunan skor dan mendapatkan kateregori dari netral menjadi rendah. Maka dari itu solusi pengendalian dampaknya, agar masyarakat tidak dirugikan dengan penurunan hasil pertanian dan pihak pengelola tetap bisa mengambil alih lahan, maka pihak pengelola Dusun Bambu harus tetap menyediakan lahan untuk pertanian dengan tetap pengelolaan berada di Dusun Bambu namun masyarakat diizinkan untuk merawat dan bercocok tanam di lahan tersebut. Keuntungan bagi Dusun Bambu bahwa adanya lahan pertanian dapat menjadi atraksi wisata bagi pengunjung Dusun Bambu, sedangkan masyarakat tidak merasa dirugikan karena masih bisa mengelola lahan pertanian. Untuk sistem hasil dari pertanian tersebut maka harus ada perjanjian terlebih dahulu antara masyarakat dan pengelola Dusun Bambu.

Solusi pengendalian dampak selanjutnya adalah pernyataan tentang tata nilai, dimana pada hasil kuisioner tata nilai kehidupan masyarakat kertawangi terjadi penurunan dari sebelum dan setelah keberadaan Dusun Bambu. Solusi menurut teori mengenai pengendalian sosial yang menyebutkan, agar masyarakat tidak melakukan penyimpangan adalah tindakan preventif. Tindakan preventif yaitu tindakan yang dilakukan sebelum penyimpangan sosial terjadi agar suatu tindak pelanggaran dapat diredam atau dicegah. Usaha pengendalian preventif dilakukan agar suatu perilaku tidak sampai menyimpang dengan norma-norm dan apabila terjadi penyimpangan itu tidak sampai merugikan yang bersangkutan ataupun orang lain. Pengendalian yang bersifat preventif umumnya dapat dilakukan dengan cara melalui bimbingan, pengarahan, dan ajakan. Kemudian perubahan yang terjadi yang dirasa merugikan masyarakat adalah pernyataan tentang kemacetan dan polusi yang terjadi setelah keberadaan Dusun Bambu.

Solusi pengendalian dampaknya pada kemacetan di sekitar jalan menuju kawasan wisata Dusun Bambu menurut Kepala Dinas Perhubungan Komunikasi dan Informatika KBB, Agus Gusman menjelaskan usulan rekayasa lalu lintas untuk mengurai kemacetan di Lembang. Rekayasa lalu lintas menurut Homburger \& Kell 1977 adalah suatu penanganan yang berkaitan dengan perencanaan, perancangan geometric, dan operasi lalu lintas jalan serta keterkaitan dengan moda transportasi 
lainnya. Sedangkan istilah rekayasa lalu lintas di Indonesia merupakan salah satu cabang dari teknik sipil yang menggunakan pendekatan rekayasa untuk mengalirkan lalu lintas orang dan barang secara aman dan effisien dengan merencanakan, membangun, dan mengoprasikan geometric jalan, dan dilengkapi dengan rambu lalu lintas, marka jalan serta pemberi isyarat lalu lintas.

Selanjutnya pengendalian untuk masalah polusi yang diakibatkan dari asap kendaraan pengunjung, ada beberapa usulan yang pertama adalah pengelola kawasan Dusun Bambu membuat lahan drop area atau lahan parkir untuk pengunjung sebelum memasuki kawasan Dusun Bambu, disekitar jalan Kolonel Masturi. Agar kendaraan tidak masuk ke lingkungan Desa Kertawangi. Pengelola harus menyiapkan kendaraan yang ramah lingkungan seperti andong atau mobil untang-anting. Hal ini pun bisa menjadi satu atraksi wisata bagi pengunjung. Solusi berikutnya untuk pengendalian pencemaran udara adalah pengelola Dusun Bambu membuat program penanaman pohon atau tumbuhan di kanan kiri jalan menuju lokasi kawasan Dusun Bambu. Akan semakin manarik lagi apabila ada ketentuan wisatawan yang berkunjung dihimbau atau diwajibkan untuk menanam pohon yang bibitnya sudah disiapkan oleh pengelola untuk ditanam di kawasan tersebut dengan diberikan semacam label nama, alamat, dan foto sehingga disamping memberikan peluang bisnis baru bagi pengelola juga memberikan daya tarik bagi wisatawan untuk mengetahui perkembangan pohon yang ditanam di kawasan Dusun Bambu.

\section{SIMPULAN}

Berdasarkan hasil analisis data dan pembahasan tentang Dampak Keberadan Dusun Bambu Terhadap Kondisi Sosial Ekonomi Masayarakat Desa Kertawangi bahwa Kondisi sosial ekonomi masyarakat desa Kertawangi sebelum dan setelah keberadaan Dusun Bambu mengalami perubahan. Kondisi ekonomi masyarakat sebelum keberadaan Dusun Bambu termasuk kedalam kategori rendah. Tingkat pendidikan masyarakat yang sebagian besar hanya meneyelesaikan pendidikan tingkat SD menyebabkan masyarakat sulit mendapatkan pekerjaan hingga akhirnya berpengaruh pada pendapatan mereka yang masih termasuk kedalam kategori rendah. Sedangkan Kondisi ekonomi setelah keberadaan Dusun Bambu masih termasuk kedalam kategori rendah. Namun terjadi peningkatan setelah keberadaan Dusun Bambu. Setelah keberadaan Dusun Bambu sebagian masyarakat dapat bekerja di kawasan Dusun Bambu sehingga menyebabkan peningkatan penghasilan. Hasil ini mengacu pada tingkat pendapatan, kesempatan kerja, harga-harga, kepemilikan, serta pembangunan fasilitas.

Kondisi sosial sebelum keberadaan Dusun Bambu termasuk ke dalam kategori tinggi. Lingkungan yang nyaman serta didukung oleh pergaulan masyarakat yang sederhana membuat kondisi sosial Desa Kertawangi berada di kategori tinggi. Sedangkan kondisi sosial setelah keberadaan Dusun Bambu termasuk kedalam kategori netral. Setelah keberadaan Dusun Bambu terjadi perubahan struktur populasi menjadi tidak stabil, tata nilai masyarakat berubah, terjadi polusi dan kemacetan yang 
mengganggu aktivitas masyarakat. Hasil ini mengacu pada struktur populasi, transformasi mata pencaharian, tata nilai, dan keseharian masyarakat.

Apabila dilihat dari perbedaan kondisi sosial ekonomi sebelum dan setelah keberadaan Dusun Bambu dan mengacu pada hasil uji paired sample t-test maka terjadi dampak yang positif bagi kondisi ekonomi setelah keberadaan Dusun Bambu. Dampak positif ekonomi terbesar yaitu terjadi peningkatan pendapatan masyarakat Desa Kertawangi. Sedangkan untuk kondisi Sosial, dengan terjadinya penurunan ratarata kondisi sosial sebelum dan setelah keberadaan Dusun Bambu maka terjadi dampak yang negatif bagi kondisi sosial masyarakat. Dampak negatif terbesar ada pada perubahan sosial lingkungan fisik Desa Kertawangi.

Upaya pengendalian dampak bagi penurunan produktivitas hasil pertanian dan peternakan yaitu pihak pengelola Dusun Bambu harus tetap menyediakan lahan untuk pertanian dengan tetap pengelolaan berada di Dusun Bambu namun masyarakat diizinkan untuk merawat dan bercocok tanam di lahan tersebut. Keuntungan bagi Dusun Bambu bahwa adanya lahan pertanian dapat menjadi atraksi wisata bagi pengunjung Dusun Bambu, sedangkan masyarakat tidak merasa dirugikan karena masih bisa mengelola lahan pertanian. Solusi pengendalian dampak selanjutnya adalah pernyataan tentang tata nilai solusi pengendalian dampak dalam masalah tata nilai ada pada teori mengenai pengendalian sosial yang menyebutkan, agar masyarakat tidak melakukan penyimpangan-penyimpangan adalah tindakan preventif. Pengendalian dampak masalah kemacetan menurut Kepala Dinas Perhubungan Komunikasi dan Informatika KBB, Agus Gusman menjelaskan usulan rekayasa lalu lintas untuk mengurai kemacetan di Lembang. Rekayasa lalu lintas. Dan pengendalian dampak terakhir mengenai pencemaran udara adalah membuat program dari pihak pengelola Dusun Bambu untuk meminimalisir pencemaran polusi seperti di buatnya program penanaman pohon atau tumbuhan.

\section{DAFTAR PUSTAKA}

Bisnis Hotel. Diakses tanggal 16 April 2015. Dari www.Bisnis Hotel.html

Domanski, B., \& Krzysztof, G. (2010). Multiplier Effect in Local and Regional Development. Adam Mickiewicz Univerity Press.

Ismayanti. (2010). Pengantar Pariwisata. Jakarta: Kompas Gramedia

Koentjaraningrat. (1990). Metode - Metode Penelitian Masyarakat. Jakarta: Pustaka Jaya

Marshall, A. (1920). Industry and Trade. Cambridge: Balliol Croft

Mill, R. C. (2000). Tourism The International Business, Rajawali Pers 
Nazir, M. (2005). Metode Penelitian. Bogor: Ghalia Indonesia.

Pitana, I. G., \& Gayatri, P. G. (2005). Sosiologi Pariwisata. Yogyakarta Penerbit: ANDI

Richardson, J. I., \& Fluker, M. (2004). Understanding and Managing Tourism. Person Education Australia, NSW Australia: Australia

Sugiyono. (2011). Metode Penelitian Kuantitatif, kualitatif dan $R \& D$. Bandung: Alfabeta

Yoeti.O. A. (2008). Ekonomi Pariwisata. Jakarta: Penerbit Buku Kompas. 